\title{
The Management of Local Wisdom Tourism of Baduy Tribe by Department of Tourism of Lebak Regency, Banten, Indonesia in Increasing the Number of Tourists
}

\author{
Farid Hamid Umarella ${ }^{a^{*}}$, Dewi Sad Tanty ${ }^{\mathrm{b}}$, Aprezia Anjanie $^{\mathrm{c}}$ \\ ${ }^{\text {a }}$ Lecturer at Faculty of Communication, Universitas Mercu Buana \\ Jakarta, Indonesia \\ Email: farid.hamid [AT] mercubuana.ac.id \\ ${ }^{\mathrm{b}}$ Lecturer at Faculty of Communication, Universitas Mercu Buana \\ Jakarta, Indonesia \\ Email: dewi.tanti [AT] mercubuana.ac.id \\ ${ }^{c}$ Lecturer at Faculty of Communication, Universitas Ibnu Chaldun \\ Jakarta, Indonesia \\ Email:anjanie1404 [AT] gmail.com \\ *Corresponding author's email: farid.hamid [AT] mercubuana.ac.id
}

\begin{abstract}
The Baduy Village is one of the tourist destinations located in Lebak Regency, Banten, Indonesia. The Department of Tourism of Lebak Regency manages the tourism potential of the Baduy tribe which is loaded with the local wisdom besides its natural beauty. This study aimed to analyze the management of local wisdom tourism of Baduy tribe by the Department of Tourism of Lebak Regency Banten, Indonesia in increasing the number of tourists. A constructivist paradigm with a case study method was used in this study. The informants were from the Department of Tourism of Lebak Regency and tourists who have been to the Baduy Village. The data collection was done through structured interviews, observations and literature studies. The qualitative data analysis technique was carried out to reveal the tourism management. The research results showed that the tourism management through promotion strategies used segmentation, targetting, and positioning approaches based on geographic, psychographic, and demographic. It also used the promotional media.
\end{abstract}

Keywords--- Tourism management; Tourism promotion; Local wisdom; Baduy Tribe

\section{INTRODUCTION}

Indonesia is an archipelagic state that has natural beauty supported by the geographical conditions and landscapes. The cultural diversity from various ethnic groups has become a tourism potential which can increase income in the business sector.

In the past decade, Indonesia has been active in development accompanied by intensive tourism promotion. Transportation access, technological advances and the improvement of consumption of tourist commodities has made many countries steadily promote the tourism, including Indonesia. This phenomenon certainly has implications for the shift in market orientation and preferences on the selection of tourism products.

Now, the promotion of tourism products is increasingly easy to find with new nuances and new designs that continue to compete in order to provide a comfortable space for tourists. The tourism products that have a distinctive nuance that emphasizes the elements of experience and professionalism, uniqueness, and quality. This can encourage the increasing tourist area in various provinces in Indonesia. The tourism sector is an alternative income for the country's foreign exchange income and regional income. Even for developed countries, it is so seriously developed.

Banten is one of the provinces of Indonesia which is located on the Java Island. This province has an area of 9,663 $\mathrm{km}^{2}$. There are many tourist destinations in Banten Province which one of them is the Baduy village located in the Lebak Regency as one of the important tourists destinations in Banten (https://dispar.bantenprov.go.id). Based on the interviews with the Head of Department of Tourism in Lebak Regency, there are 23 tourist destinations. One of the most prominent and iconic destinations is the cultural tourism of the Baduy Village. The Baduy Village is one of the tourist destinations located in Lebak Regency, Banten. The Baduy Tribe which is until now still maintains ancestral customs and refuses modern life can attract tourists who are curious about the life of this tribe. Therefore, the Department of Tourism of Lebak Regency preserving and promoting this tribe. Certainly, a strategy that is planned according to the government programs is needed.

The marketing strategy at the destination level should begin with research to identify the target market of the relevant 
tourism destination and the right promotion and branding strategy for the target market. Through the promotion strategy, it is expected to be able to help tourism in Lebak Regency to be better known not only by the Lebak people but also outside communities. It is also expected to be able to compete with tourism in other regions (Suryadana and Octavia, 2015, p.97).

Based on the background above, this research was conducted to analyze the management of local wisdom tourism of Baduy tribe by Department of Tourism of Lebak Regency in increasing the number of tourists to the Baduy Village. Thus, this research is expected to contribute in providing input on the development of tourism potential in the Lebak Regency, Banten Province.

\subsection{Marketing Communications}

\section{LITERATURE REVIEW}

Marketing communications can be interpreted as communication between producers, intermediaries, marketers, and consumers which help consumers to make decisions in marketing and direct exchanges or transactions to be more satisfying by making all parties aware of thinking, doing, and behaving better (Sangaji, 2013, pp. 225). Kotler \& Keller (2006) state that marketing communication as a way that companies use to inform, persuade, and remind consumers directly or indirectly about the products and brands they sell. It represents the brand and is a way used to build dialogue and relationships with consumers.

Marketing is a managerial and social process that groups or individuals obtain what they need and want by offering, exchanging, and creating something (Jamal \& Getz, 1996, pp.186-205; Kotler \& Gertner, 2002, pp. 249-261). Marketing is a whole system in the context of business activities (Synodinos, 1990, pp.161-170). These activities are aimed at planning, pricing, promoting, and distributing goods and services according to the needs of consumers. There are three main elements in the marketing concept: (1) Consumer or market orientation; (2) Favorable sales volume; (3) Coordination and integration of all marketing activities.

\subsection{Promotion and Promotion Mix}

Promotion is an important part of marketing methods (Beirman, 2003, p. 1146). Tourism companies must use marketing strategies for their products so that the promotion can run effectively. Rowley (1998) supports that promotion is a one-way flow of information or persuasion to direct a person or organization for actions that create exchanges in marketing. It can be concluded that strategy and promotion are interrelated in marketing activities (Rowley, 1998, pp. 383387).

The promotion has five functions that are very crucial for a company, namely (1) informing or providing valuable information, both for the advertised brand and its consumers, by teaching the new benefits from the existing brands; (2) persuading or convincing by creating demand for the entire product category even building secondary demand, demand for specific brands; (3) reminding the consumers who have not recently bought available brands and contain beneficial attributes; (4) adding value or improving value through innovation, consummation, quality or changing consumer perceptions so that the product looks more elegant, more stylish, more prestigious and superior to competitors' offers; and (5) assisting or accompanying other efforts of the company in sales, prospecting and legitimizing or making what the claims by the seller's representatives are more credible (Shimp, 2000, pp 6).

According to Mangold and Faulds (2009), the promotion mix is an effective combination of various strategies including variable advertising, personal selling, and other promotional tools, all of which are planned to achieve the objectives of the sales program (Mangold \& Faulds, 2009, pp. 357-365). Then Kotler \& Keller (2009) mention word of mouth marketing is oral, written, and electronic communication between communities that relates to excellence or experience buying or using a product or service. This promotion is the most effective way to influence the consumers in marketing goods and services (Kotler \& Keller, 2009 pp. 174).

\subsection{Promotion Strategy}

The promotion strategy is communication with consumers by sending messages about the condition of a product. Promotional activities must be well planned to create a conducive atmosphere where consumers can obtain information and then become interested in the product being promoted. Related to the promotion that consists of various activities and models that have various elements that can be combined; this condition is called media promotion (promotion mix) (Briandana at al, 2018, pp. 604).

In the context of tourism, a promotion strategy is a series of activities to notify the product or service to be offered by providing information or convincing potential consumers about the usefulness of a product or service to encourage consumers to either continue or start buying at a certain price (Manahati, 2006, pp 28). However, it can be concluded that the promotion strategy is integrated planning and supplementation of a set of actions that aim as a persuasive communication tool carried out by the company to market its products.

\subsection{Tourism Promotion Techniques}

The promotion techniques used by travel agents to promote tourism, namely advertising, sales promotion, personal selling, and public relations (Suryadana, 2015, pp. 163). Advertising or popular as advertising in service marketing is to 
build awareness of potential buyers of the services offered, persuade prospective buyers to buy, want to use these services and to differentiate services from one company with another company.

Sales promotion is one of marketing activities other than advertising that encourage the effectiveness of purchasing consumers and intermediary traders by using promotional tools. The method often used is the provision of discounts, lottery coupons, and cash refunds by reducing the price given to buyers specified in the form of a percentage or unit of rupiah. Furthermore, the personal selling or face to face selling is a communication activity between producers represented by salespeople with potential consumers that involve emotional thoughts and face to face with buyers. This technique can be done directly with face to face with potential buyers, for example in the tourist market (travel mart). Then public relations relate to all communication efforts to determine and maintain open two-way communication with all levels of society and create good public opinion about tourism products offered by the company.

\subsection{The Segmenting, Targeting and Positioning Model (STP)}

Service market segmentation is part of the activities carried out by service marketers to find customers who are expected and desired. According to Kotler there are two approaches to market segmentation, namely consumer characteristics, and segmentation based on consumer response. According to Nirwana (2004) segmentation based on consumer characteristics can be defined based on (1) demographic means the marketer must be able to choose the existence of consumers based on population structure and population criteria that are being used as sales targets for these services. (2) psychographics which sorts out their target markets based on psychological conditions, including purchases, buying habits, and buyer behavior; and (3) geographical or segment based on the region where the consumer is located, both in the scope or small or wider area (Nirwana, 2004, pp. 60).

Targeting is an effort to determine the market target which is the next stage of the marketing communication strategy. It has two functions at once, namely selecting the target market according to certain criteria and reaching the target market (Kennedy \& Dermawan, 2006). The positioning is not a product strategy but is a communication strategy in the cognition of consumers in relation to other competing brands.

\subsection{Tourism}

Tourism is a temporary activity carried out by individuals and groups to enjoy a trip and also to meet diverse desires. Tourism products are a series of products (goods and services) selected for tourists' use or consumption during their tour. These products are in the 'operating sector' of the tourism industry. This includes sectors that represent what the general public considers the concept of 'tourism' (Goeldner \& Ritchie, 2012).

According to Suwena (2017) Tourism can be studied not only in terms of motivation and purpose of travel but also can be seen in the forms of travel. The forms of tourism according to the geographical location are differentiated into local tourism, regional tourism, national tourism, regional-international tourism, and international tourism (Suwena \& Widyatmaja, 2017, pp. 17).

According to IUOTO (International Union of Official Travel Organizations), in Gamal Suwantoro (2009) uses restrictions on tourists in general: visitors are people who come to a country or other place of residence and usually for any purpose except to do work that receives wages (Suwantoro, 2004, p. 4).

So, there are two categories regarding the designation of visitors, namely first, tourists are visitors who stay temporarily, at least 24 hours in a country with two kinds, namely cruise (leisure) and relationship. Second, travelers (excursionists) who temporarily live in a country that is visited in less than 24 hours.

\section{METHODOLOGY}

The approach used in this research was qualitative analysis in certain cases. In the study, the researchers analyzed the marketing promotion process carried out by the Department of Tourism of Lebak Regency. Thus, a more specific understanding was built on the development of theory, which was a collaboration of specific theories (Gioia \& Hamilton, 2013, pp. 15-31). The qualitative analysis was also chosen in this research related to the need to explore and explain phenomena and to develop theories. Then this research used a case study design. According to Yin (2008), a case study is an empirical inquiry that investigates phenomena in real-life contexts, when the boundaries between phenomena and contexts do not appear explicitly and where multiple sources of evidence are utilized (Yin, 2008, p. 1).

The data collection was done through structured interviews and observations. Then through the process of data reduction, data display, and data verification. The interviews were conducted with informants from the Department of Tourism of Lebak Regency, then to tourists, as well as tourism industry businesses. The interviewees are Hayat Syahida (The Head of Department of Tourism of Lebak Regency), Oktaviano (The Head of Lebak Regency Tourism Marketing); Endah (The Head of Tourism Promotion Section of the Department of Tourism of Lebak Regency) and Fazry and Veronica Puspanigtyas, both tourists from Jakarta who had been to the Baduy Village.

To ensure the validity of the data, the researchers conducted the process of checking the validity of the data. Ariani and Novi (2019) explain that to check the validity of the data by applying the technique of comparing and checking back the degree of trust in the information obtained by: (1) comparing observational data with interview data (2) comparing the consistency of the respondent's answers, namely by comparing what the resource person said in public for example, with what was said privately (3) comparing one's perspective, with others on the team it works (Ariani \& Novi, 2019, p.2). 


\section{RESULTS AND DISCUSSION}

The Baduy village is one of the destinations owned by Lebak Regency and is often visited by foreign tourists because it has its uniqueness.

The Regional Regulation Number 8 of 2016 concerning Permit for Implementation in the Field of Tourism. The decree of the Regent of Lebak regarding the delegation of authority to the Head of the Department of Tourism of Lebak Regency to issue permits for implementation in the field of tourism (Department of Tourism of Lebak Regency, 2016).

The Department of Tourism of Lebak Regency has the responsibility to realize Lebak Regency Tourism on an ongoing or sustainable basis. Even set a vision of " Realization of Lebak Regency Tourism which is Competitive and Based on the Regional Potential"

To realize the vision above, the Department of Tourism: set out a mission to compile a data collection and master plan of the tourism zoning area based on regional zoning; carry out arrangement and develop the regional zoning-based attraction; carry out domestic and foreign tourism promotion through print media, social media, electronics and exhibitions; organizing events in Lebak Regency and increasing the capacity of Tourism Human Resources.

Seba Baduy and the Baduy Festival are annual activities carried out by the Department of Tourism of Lebak Regency. Seba Baduy which is originally an annual tradition of Baduy people. where the Baduy community handed over the produce to the Regional Head.

Seba Baduy is included in the 7 Wonders of Banten and is included in the 100 Wonderfull Indonesia Tourism Events. It has attracted a lot of attention both for the local community and for the local and foreign tourists. There are several activities in Seba Baduy including fossil stone exhibitions and festivals as well as photography competitions on site.

\subsection{Research Results}

The tourism sector is one of the factors affecting the Lebak Regency Economy. The tourism of the Baduy Village is a tourist destination which is a wealth of its own for this area. The Department of Tourism of Lebak Regency, is an agency responsible for the Lebak Regency government environment in the field of tourism. To carry out the function of cultural and natural utilization, the cultural tourism of the Baduy Village must utilize its tourism by increasing the number of visitors.

\subsubsection{Baduy Community Development}

The main factor that was carried out was developing the Baduy community with all its potential. The Baduy trible is an isolate tribe. They build their own live both in agriculture, economics, and social relations. This tribe deliberately isolate themselves. A tribe that holds tight values and norms, traditions loaded with the existing local wisdom.

This trible is located in lebak Regency, Banten Province. Baduy is located in the village of Kanekes located on Mount Kandeng which is part of the forest. Some of the characteristics of this tribe are that they live independently and do not depend on others and expect help from outsiders. This codition is supported by the geographical location of the village of Kanekes which consists of hills and requires a lot of time to reach its location.

This tribe avoids itself from outside influences and holds firmly to tradition. The Baduy live in harmony with nature, preserving nature. Economically, the Baduy activity is only to fulfill daily needs and is produced and consumed within the Baduy environment itself. A simple lifestyle that is far from materialistic.

The Local wisdom in the Baduy community gives its attraction, especially in this modern era. So many individuals or groups come and visit the Baduy tribe village.

The Regional Government of the Lebak Regency through the Department of Tourism made various efforts to develop the Baduy community so that they would be brave enough to raise their local potential. For example, through mentoring in terms of the creative economy in the form of the uniqueness of how to eat with cutlery made of bamboo, rattan plates, and hangers from bamboo. This potential is used to provide its color for the local wisdom-based tourism.

\subsubsection{Tourism Community}

The increasing of the number of tourists is certainly needed a good marketing communication strategy. The promotion carried out by the Department of Tourism of Lebak Regency is by moving the tourism community.

The tourism community is spearheaded in promoting tourism in the Baduy Tribe Village. The tourism community such as Pokdarwis, Genpi, Backpacker National Genpi. Currently, Lebak has Lebak Genpi which consists of Pokdarwis, Backpacker. We also have tourism ambassadors namely Saija and Adinda. Besides, this tourism community is connected with the media. Interestingly all these tourism activists in the tourism community work voluntarily.

\subsubsection{Tourism Promotion Strategy of the Baduy Village}

Based on the interviews with the Head of the Creative Economy Section of the Department of Tourism of Lebak Regency, it was found that the tourism promotion strategy was planned using STP analysis or Segmentation, Targeting, and Positioning. It began to do by determining the segment to be addressed to students and college students.

In the segmentation stage, it is widely applied to the general public. After knowing the specified segmentation in promoting the cultural tourism of the Baduy Village, the next is the targeting stage. In this stage, it was selected one or 
more market segments that will be targeted by the target market, namely tourist visits and an understanding of a culture so it will not to become extinct.

After the company determines the market segments that will be entered, they continue to the next stage namely positioning. It is as a form of promotion of cultural tourism for students or college students. It was executed with the unique slogan Lebak is unique and so is Baduy.

Furthermore, through the Tourism Working Group system, a promotional action is planned. Also, human resources and programs and activities are strengthened. In its implementation, a website and application (Lebak Unique) were created to support the Seba Baduy event.

In carrying out the promotional programs to carry out advertising related to the Baduy Village tourism namely: television, print media, and radio, social media. The selected television is Baraya TV (Banten Raya TV) which is a Banten local television station, several national tv and radio broadcasts. As stated by the Head of the Department of Tourism, Hayat Syahida.

We also have advertorial, there is cooperation with the media. Especially local media like Baraya tv and also radio. It also often appears on national tv about Baduy. For national tv, there may be reporters who are indeed able to cover Baduy because we do not have cooperation with national. This is related to the budget"

The strategy undertaken by the Department of Tourism of Lebak Regency in promoting cultural tourism of the Baduy Village was by analyzing and seeing which segments were right through the promotional mix and also in collaboration with print and mass media.

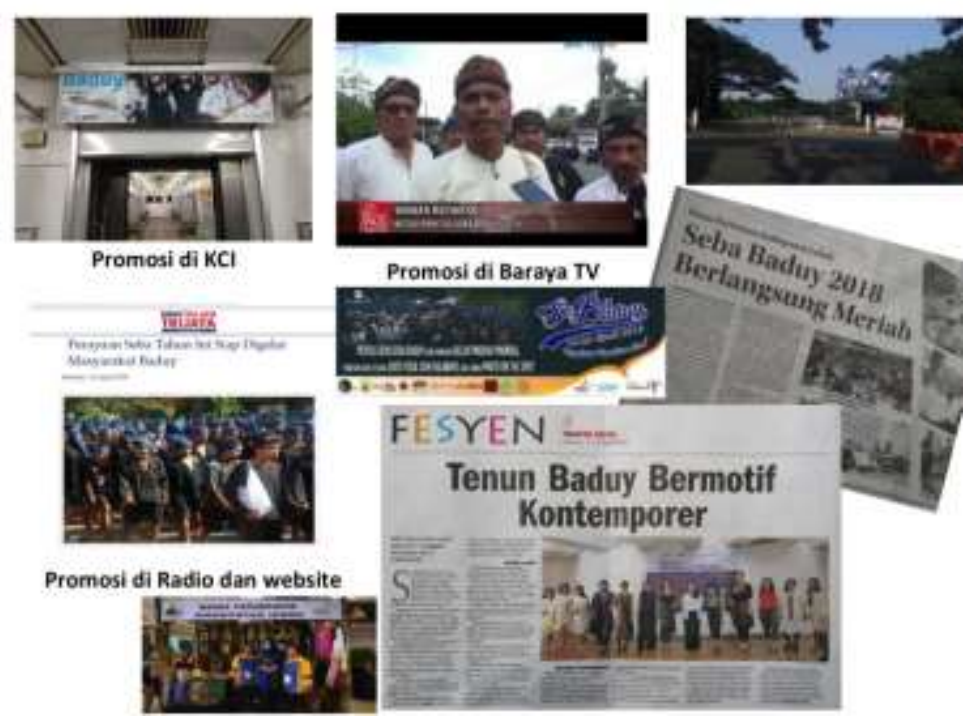

Figure 1. The Variety of Promotion Activities in the Department of Tourism of Lebak Regency Sources: Research Results

Following the results of the interview with Endah as the Head of Promotion Section of the Department of Tourism of Lebak Regency:

"First, our promotion strategy is analyzing which segment we want to go to. Then we determine the promotional mix through collaboration with print, online, mass media such as radio and local tv. Then we also have Saija and Adinda (Ambassador of Tourism in Lebak Regency). We also have Genpi (Generasi Pesona Indonesia) which helps the Department of Tourism of Lebak Regency in its efforts to promote Baduy".

The same thing was shown by the Head of Marketing of the Department of Tourism of Lebak Regency, Oktaviano Arief who said that the Department of Tourism of Lebak Regency involved several media and cooperated:

To promote activities that are held by the Department of Tourism of Lebak in Baduy, such as the Seba Baduy, the collaboration was carried out. One of which we involve and cooperate with existing local media, such as Baraya tv. We also appeal to all agencies in Lebak to put up billboards about this Seba event and also collaborated with KCI (Indonesian Commuter Train) where several Commuter cars were tucked into advertisements about destinations in Baduy, especially destinations that are featured such as Baduy, Sawarna, Badegur, and also Museum Multatuli ." The findings regarding the promotion program can be summarized in the following matrix: 
Matrix 1. Tourism Promotion Activities of the Baduy Village

\begin{tabular}{|c|c|c|}
\hline No & Promotion Mix Element & Forms of activity \\
\hline 1 & Advertising & $\begin{array}{l}\text { a. Television commercials. The news about the Seba Baduy } \\
\text { event on Baraya Local TV } \\
\text { b. Radio Advertising. Local radio Multatuli Fm, Trijaya Fm } \\
\text { Jakarta } \\
\text { c. Billboard Advertising. Mounting in the Rangkasbitung } \\
\text { square about the Seba Baduy event } \\
\text { d. Advertising on Commuter Trains. Mounting posters about } \\
\text { Baduy }\end{array}$ \\
\hline 2. & Personal Sales & $\begin{array}{l}\text { By attending a number of tour events held by the Ministry of } \\
\text { Tourism or by Private Party }\end{array}$ \\
\hline 3. & Publication & $\begin{array}{l}\text { Brochure about the Seba Baduy event, a leaflet in the form of a } \\
\text { tourist destination map in Lebak Regency, as well as the } \\
\text { distribution of multi-trip commuter train cards. }\end{array}$ \\
\hline 4. & Word of Mouth & $\begin{array}{l}\text { This form of promotional activity is created on the } \\
\text { recommendation of one person to another person who told the } \\
\text { positive side of the Baduy Village. }\end{array}$ \\
\hline 5. & Public Relation & $\begin{array}{l}\text { Hold an international scale event because the Seba Baduy event } \\
\text { is included in the } 100 \text { Wonderfull Indonesia Tourism Events. }\end{array}$ \\
\hline
\end{tabular}

Sources: data processing

From the matrix above, it can be seen that the promotion was done through commuter line trains. It was also through local TVs such as BarayaTV, Multatuli Local Radio, Jakarta TrijayaFM Radio, and website. Banten Raya is a local print media that reports on the excitement of the Seba Baduy event. The news was getting bigger to reach people to come to this annual event or to come to Baduy.

It was same with the news of the city newspaper. This article writing is related to the Baduy Weaving which is made more contemporary in the fashion rubric. Besides, there was the installation of billboards in the Rangkasbitung square about the Seba Baduy event.

The Department of Tourism of Lebak Regency also conducted seminars to the universities in Lebak Regency and conducted recovery to the perpetrators of the tourism, as well as holding an international scale event because it has entered into one of the 100 Wonderfull Indonesia Tourism Events such as Seba Baduy, as well as the Baduy festival.

The Department of Tourism of Lebak Regency participated in exhibitions that were often held by the government in various regions of Indonesia and also the private sector. However, the Department of Tourism of Lebak Regency did not run a sales promotion. It was more to publications or promotional activities carried out through printing leaflets, brochures, bulletins, books, and magazines. The publication activities planned and carried out by the Department of Tourism of Lebak Regency. The same thing was said by Ms. Endah as the Head of Promotion Section.

The Word of mouth promotion conducted by the Department of Tourism of Lebak Regency was to invite friends, family to come on a trip to Baduy. This was also conveyed by Veronica Puspaningtyas as a local tourist, Veronica said that she learned about the Baduy tribe from her friends who at that time were indeed educated in Serang City.

I found out about the Baduy Village from my campus friends. Just in chance, I study in Serang therefore so many of my friends who had visited Baduy before."

The promotional activities carried out include organizing events supported by several government agencies, and other private agencies and involving the community and students and also college students in Lebak. The purpose of the tourism promotion of the Baduy Village is to inform prospective tourists about the benefits gained by potential tourists in terms of cultural tourism. The information presented about the local wisdom of Baduy culture and its natural products.

\subsection{Discussion}

Based on the results of the study, it can be understood that the promotion carried out by the Department of Tourism of Lebak Regency is aimed at maintaining Cultural values in the Baduy Village. The purpose of the promotion is increasing the number of tourists to come to the Baduy Village.

The Department of Tourism of Lebak Regency promotes using electronic media such as television, radio, advertising media such as billboards, banners, brochures, magazines, newspapers, and internet media. The promotion and information both play an important role because with the promotion and information about attractions, people will know and indirectly will give a sense of curiosity about these attractions. From this process, there will be a visit to the tourist destinations as a form of curiosity and proof of what is promoted and the information obtained. 
The interesting thing, the visitors also have an important role in promoting an object and tourist destination, indirectly they have role as agent of promotion carried out by word of mouth promotion. The Department of Tourism of Lebak Regency conducted several promotions to promote the Baduy Village by using six promotional mix elements except for sales promotion.

Another interesting finding, there are obstacles in the Department of Tourism of Lebak Regency to promote all existing destinations. However, in this case, the Department of Tourism of Lebak Regency felt helped by the formation of the Pokdarwis and also the Tourism Concern Generation (Genpi), which had helped to neutralize tourist destinations in the Lebak Regency especially the Baduy Village and the Seba Baduy event.

\section{CONCLUSION}

The research on the management of local wisdom of the Baduy tribe by the Department of Tourism of Lebak Regency in an effort to increase the number of tourists in the Baduy Village showed that the promotion strategy was carried out by analyzing which segments were appropriate using segmentation, targeting and positioning approach based on geographical, psychographic and demographic. Regarding the use of promotional media used mass media, both print, electronic and online mass media; create booklets and leaflets that contain information as a guide book on the Beauty of the Baduy Village, Cooperate with KCI (Indonesian Commuter Train), as well as various major events including exhibitions and holding seminars and socialization to tour operators.

\section{REFERENCES}

- Ariani, Afrilia Christina and Novi Erlita. 2019. The Public Relations Activities of Taman Impian Jaya Ancol, Ldt in Promoting Jakarta Tourist Attraction. Saudi Journal of Humanities and Social Sciences, Vol 4, Issue 11, pp.2

- Beirman, D. 2003. Restoring tourism destinations in crisis: A strategic marketing approach. Oxford: Oxford University Press

- Briandana, Rizki., Caturida, M.D., and Danto, S. 2018. Promotion Analysis of Marine Tourism in Indonesia: A Case Study. European Research Studies Journal Volume XXI, Issue 1, pp. 604

- Dinas Pariwisata Provisnsi Banten. Profile Provinsi Banten. Internet: https://dispar.bantenprov.go.id/Profil/topic/50 date accessed August 20, 2019

- Gioia, D.A., Corley, K.G. and Hamilton, A.L. 2013. Seeking qualitative rigor in inductive research: Notes on the Gioia methodology. Organizational Research Methods, Vol 16, Issue 1, pp 15-31.

- Goeldner, C.R. and Ritchie, J.R.B. 2012. Tourism: principles, practices, philosophies. John Wiley and Sons, Inc

- Jamal, T.B. and Getz, D. 1995. Collaboration theory and community tourism planning. Annals of tourism research, volume 22, Issue 1, pp. 186-204

- Kennedy, Jhon E. and R. Dermawan. 2006. Marketing \& Communication: Taktik \& Strategi. Jakarta: PT. Buana Ilmu Populer

- $\quad$ Kotler, P. and Gertner, D. 2002. Country as brand, product, and beyond: A place marketing and brand management perspective. Journal of brand management, volume 9 issue 4, pp. 249-261

- Kotler, P. and K.L.Keller. 2009. Marketing Management, 13th Ed, NJ: Pearson Education, Inc, Upper Saddle River

- $\quad$ Kotler, Philip and Kevin Lane Keller. 2006. Marketing Management, $12^{\text {th }}$ Edition. California: Prentice Hall

- Manahati Zebua, Pemasaran. 2006. Pariwisata: Menuju Festival Sail Daerah. Yogyakarta: Deepublish

- Mangold, W.G. and Faulds, D.J. 2009. Social Media: The New Hybrid Element of The Promotion Mix. Business horizons, volume 52., issue (4), pp. 357-365

- Nirwana. 2004. Prinsip-prinsip Pemasaran Jasa. Malang: DIOMA

- Rowley, J. 1998. Promotion and marketing communications in the information marketplace. Library review, volume, 47., issue 8, pp. 383-387

- Sangaji, Etta Mamang. 2013. Perilaku Konsumen Pendekatan Praktis Disertasi Himpunan Jurnal Penelitian. Yogyakarta: Andi Offset

- Shimp, Terence A. 2000. Periklanan Promosi Aspek Tambahan Komunikasi Pemasaran Terpadu. Jakarta: Erlangga

- Suryadana, M. Liga and Vanny Octavia. 2015. Pengantar Pemasaran Pariwisata. Bandung: Alfabet

- Suwantoro, Gamal. 2004. Dasar-dasar Pariwisata, Yogyakarta: Andi Offset

- Suwena, I Gusti and I Gusti Ngurah Widyatmaja. 2017. Pengetahuan Dasar Ilmu Pariwisata. Denpasar: Pustaka Larasan

- Synodinos, N.E. 1990. Environmental attitudes and knowledge: A comparison of marketing and business students with other groups. Journal of Business Research, volume 20 issue 2, pp.161-170

- Yin, Robert K. 2008. Studi Kasus (Desain Dan Metode) (Case Study Research Design and Methods). Jakarta: PT.Raja Grafindo Persada 